\title{
Introduction
}

\section{My Way to (Neo) Ḥasidism}

\section{Alterity}

Alterity. For me, as a young secular Jew from the flesh-pots of the New York suburbs, from Jewish Workman Circle summer camp and a mixed-race public school where popular culture was all that was sacred, that is what Hasidism and hasidic life represented: the promise of alterity. Of course, I had never even heard the word "Hasidism" until I was at least ten or eleven and, even then, only in books. The word was never uttered at home. Perhaps it is more accurate to say, then, that as long as I can remember, alterity more generally was something that intrigued me, the notion of living or being "otherwise," as Levinas taught me many years later. I saw myself as different, but not different enough to feel alienated, just different enough to feel like the suburban life I was experiencing was not all there was, and also was not enough. But being alienated was part of the counterculture I was reared in, so that alienation was itself that which produced cohesiveness.

It was in my teens when I first read Jack Kerouac's On the Road and came to realize alterity was something people actually embodied. It was a

1 I am intentionally not discussing my personal life in this introduction, including marriage and children, as I want to focus on the trajectory that brought me to Hasidism, led me away from it, and then brought me back again. This introduction seeks to frame the trajectory that led to the essays in this volume that were written over the course of the past twenty years or so. 
short time between that first reading of Kerouac and when I drove off in my 1972 Volkswagen minibus on New Year's Eve 1977 that took me literally "on the road" to the mountains of New Mexico with no purpose other than to experience the feeling of being unbound, what I later came to know as the notion of "lishma": that wonderful experience where there is no place of arrival other than where you happen to stop at the end of the day. Of course, such freedom, even the possibility of such experiential liberation, is a privilege of a middle-class life with a safety net that was not fool-proof but strong enough so that you needn't worry that you would end up homeless and destitute with no one to call-the way Neal Cassidy ends up in flop houses on the Bowery or on the streets of Denver in On the Road. I did not have the courage to take it to that extreme but I played around the edges. Not exactly a hitchhiker with a credit card (there were plenty of those too) but certainly one with a phone number where people who loved you would likely answer, scold you, and then wire the necessary money to get you out of a jam. I remember some of those calls with both trepidation and gratitude. For some reason when I left home all my father gave me was a gas credit card, hoping, I assume, I would not run out of gas on some abandoned road on the fruited plain.

But the road to Jewish alterity for me began even earlier in my childhood, if only in my imagination. My paternal grandmother, an immigrant from the Pale of Settlement, used to take me on annual trips to places outside the bubble of New York. One year we visited what was then called "Amish country" in Pennsylvania. What struck me a child of the gilded suburbs was the simplicity-what the Amish call "plainness"-of their lives. It was perhaps my first real experience that it was possible to live "otherwise." The smell of hay, the rural rolling green hills, shoofly pie (an Amish delicacy made of molasses and pie crust), and the horse-drawn carts offered a world I hadn't known existed. The second memory was during trips to visit relatives in Brooklyn. We would often take the Brooklyn-Queens Expressway which runs right under the hasidic enclave of Williamsburg. As a child I recall getting glimpses of hasidim stroll on the overpass as we sped by underneath wondering who they were and how they lived. I knew I was a Jew and they were Jews but I could not understand what tied us together. The connection between hasidim and the Amish, and Christianity, remained strong throughout my childhood and even into adulthood, when I discovered Thomas Merton and became enthralled with monastic Christianity, or when I published an essay on the Mennonite theologian John Howard Yoder.

The door to Jewish alterity may have first appeared to me explicitly as a child of about ten or eleven when I read Chaim Potok's My Name is Asher 
Lev at the behest of my mother, whose suggestion was based on artistic talents that I exhibited as a burgeoning adolescent. At that time, and perhaps until about 16, if I seriously thought about my future it was likely as a painter. Inadvertently, Asher Lev also introduced me to the strange and compelling world of Hasidism. But also, Hasidism as rebellion, not against the world but against itself. The final scene in the book, the ultimate moment of hasidic rebellion, was when Asher Lev, having already left his hasidic world for the art world in Greenwich Village, paints a large crucifixion. And the man hanging on the cross is none other than his hasidic father. Many years later I would publish a book, Hasidism Incarnate, and use Marc Chagall's "Yellow Crucifix" as the cover, having no recollection of that final scene in Asher Lev that was so arresting to me as a young boy.

This sense of Hasidism as alterity occurred to me, decades later, soon after I moved to Boro Park, Brooklyn, to study in yeshivah and begin my life as a haredi Jew. I was walking down a side street one evening in autumn and happened upon one of the many hasidic synagogues in the neighborhood. On the outside wall there was a sign announcing a shiur (Torah class) by a well-known rabbi. In English and Yiddish the sign read: "Come hear this great sage, Mozei Shabbos, parshat Noah." What struck me was not the rabbi, who I had never heard of, or even "Mozei Shabbos" which in Boro Park is simply Saturday night. What struck me was there was no date given except "parshat Noah." I realized that in this world, time was marked not by the English calendar and not even by the Jewish calendar but by the Torah reading that will be read in synagogue that week. All the Jews in Boro Park knew the date by the parashah of the week. A non-Jew passing by, or even a secular Jew from the outside, would not know the date of this lecture. There was an experience of alterity in that moment that was exhilarating. Time marked only by Torah — in the middle of New York City.

\section{II}

\section{Macrobiotic New Mexico, the Holy Land, and the Holy}

After a brief stint living in Albuquerque after dropping out of college in 1977, I moved north near Santa Fe, and I found myself living in a macrobiotic impromptu commune of sorts in the small hamlet called Galisteo, populated mostly by Native Americans, Mexicans, a few old-timers, and hippies. It was in Santa Fe where I came to know Bill Rosenberg, a New York Jew who was a practicing acupuncturist and macrobiotic healer who had lived 
for a short time in Denver, where he came across Rabbi Shlomo Twersky, an iconoclastic hasidic rabbi who had attracted many ba'alei teshuvah to his small circle. The Twersky family rose to notoriety in Chernobyl in the late eighteenth century with a hasidic master Menahem Nahum Twersky. The dynasty then migrated to Tolne, Skvere, and other locales before settling in America and Palestine/Israel. In America one branch of the family settled in Milwaukee and then moved to cities like Pittsburgh and Boston. Rosenberg had touched Judaism lightly in those days, and being the only two Jews in our small circle we bonded and remain in touch to this day. Bill is now Ze'ev Rosenberg, an Orthodox Jew who teaches Eastern medicine at the Pacific College of Oriental Medicine in San Diego. Rosenberg played an important role for me because he gave me what was perhaps my first Jewish book in about 1977, a copy of the recently published Fragments of a Future Scroll by a rabbi named Zalman Schachter (later Schachter-Shalomi). A meandering hodgepodge of reflections, translations, and inspirational writing, Fragments was my first entry into the literary world of Hasidism , admittedly through a neo-hasidic lens. Studying macrobiotics and oriental medicine had primed me for what was to come, but it was Fragments that made me decide to take my minibus back east and make some money to visit the strange country called Israel that I knew nothing about.

I returned to Manhattan some time that spring. Working as a street messenger by day and a dishwasher in a macrobiotic restaurant by night and sleeping on a futon on the floor in my parents' modest Manhattan apartment, I soon saved enough to buy a one-way ticket to Israel with no definite plan to return. As a child I knew nothing about Israel. My family were Workman Circle people and much of what I knew about being Jewish came from attending the Workman Circle Camp Kinder Ring on Sylvan Lake, near Hopewell Junction, NY. We rarely if ever spoke about Israel, learned Yiddish and not Hebrew, and knew more about socialism than Zionism. So when I boarded the plane to Israel I carried no ideological baggage at all, something friends later have attributed to the ease with which I was able to adopt a leftist political stand on matters of Israeli politics and policies.

Over the course of a few months travelling alone and with some people I met on the way, I came upon a small group of young yeshivah students very much like myself, who happened to also be macrobiotic. On their prodding I attended a few classes in a run-down yet charming building that housed the Beit Joseph Novordok yeshivah on Shmuel ha-Navi Street in Jerusalem. The yeshivah where I was attending-known as "Brovinders," led by an American rabbi, Chaim Brovinder-was renting space from the Novordok 
yeshivah which consisted of a few dozen seemingly ill-adjusted paleskinned students who seemed to come straight out of a Roman Vishniac photograph. The founder of this group was an ascetic man in Russia named R. Yosef Yuzel of Novordok (1847-1919), a by-product of the Mussar movement of R. Israel Salanter. Known for their ascetic practices and introverted piety, Novordokers were strange birds even in a fairly strange world. My most vivid memory of them was that fifteen minutes before minhah (the afternoon prayer recited at $1 \mathrm{pm}$ in many yeshivot before lunch) they would close their gemaras (talmudic tractates), gather in the front of the cavernous sanctuary, and engage in an act of collective crying. It was actually quite startling to witness a group of young men crying together, bemoaning their unworthiness and blemished selves, imperfect servants of God trying to stay away from the temptations that swarmed all around them. Many of us Americans smirked at such overt piety but I secretly admired it.

I began to attend classes in the yeshivah more frequently until I enrolled full-time and moved in with the group of friends living in a small apartment in new haredi neighborhood, Sanhedria Murkhevet, about a 20-minute walk from the yeshivah. Without realizing it I had become a yeshivah student, cut my hair, removed my earring, and delved into the bizarre and fascinating world of the Mishnah and Talmud. I came with no background in Hebrew and thus struggled massively during that period, but those around me were kind, helpful, and compassionate. In particular, Rabbi Brovinder become a mentor for me; his intellectual rigor and biting sense of humor kept us sane in a world that otherwise appeared like a parallel universe to many of us. He taught us how to "learn," how to think inside a talmudic sugya, and also how to not take ourselves too seriously, the last being the most challenging for many of us. In those years (the late 1970s) the baal teshuvah movement was still in its heyday, Jerusalem was an open city (walking through east Jerusalem at night was not something we worried about), Israel was cheap (it had not yet moved from the Lira to the Shekel), and private telephones were rare. We had no televisions, and radio was useless since we were not yet fluent in modern Hebrew. We felt blessedly cut off from our American roots and lived a kind of reflexive orientalist existence in a world that resembled that of our great-grandparents and not our parents. I smelled the fragrance of alterity in the multi-ethnic Jerusalem neighborhood of Bukharim where we hung around after classes ended, a neighborhood that housed both the austere Novordok yeshivah and the hedonistic Turkish baths.

The four or five people I lived with became close friends. They were all students of some enigmatic and mysterious hasidic rabbi who lived in 
America named Dovid Din. They spoke of "Dovid" with a rare combination of intimacy and reverence, telling stories about his intense pious behaviors, such as praying the morning service for three hours or his long daily immersions on the mikveh, and about his bad teeth. Tales of his brilliant Torah discourses that spanned the spectrum from the sixteenth-century kabbalistic teaching of Isaac Luria to the poetry of William Blake or the Sufi poet Rumi. He was also a strict macrobiotic. He had sent his "boys" (as he called them) to Jerusalem to become literate in Talmud and codes. Intrigued by these stories I became a kind of vicarious student to this unknown teacher, and after some time I realized I needed to meet him.

There were a variety of reasons I first left Jerusalem that spring but meeting Dovid was certainly one of them. Returning to Manhattan I had no immediate plans and spent some time studying shiatsu massage at the Shiatsu Center in Manhattan. I was also able to get the address of a place where Dovid was teaching in Brooklyn and made my way there to meet what for me had already become a mythic figure. My first memory of him is a bit vague. He was giving a class in an unaesthetic study house in Flatbush with oil-cloth tablecloths and fluorescent lights. He was indeed an ethereal figure, almost transparent, dressed in Satmar-style hasidic garb (including stockings and knee-length pants) and wearing a scarf in the early summer. After the class I went to introduce myself. He seemed to recognize my name as my Jerusalem friends must have mentioned me, but he made no indication of any interest in who I was. Just another traveler passing through, he assumed. "Ah yes, I heard about you," he almost whispered. "Shalom aleikhem," he said, and put out his white, bony, and very feminine hand.

I was resolute to make myself known to him and began attending meetings more frequently, befriending some of the misfits and vagabonds who often frequented his classes. It was a hasidic underworld of sorts, lost souls wandering the streets of lower Manhattan looking for some Jewish satori. Then there were a few middle-aged female university professors who saw something in Dovid that we didn't. A few of them became his benefactors. There were also some "normal" hasidic Jews who came as well, but they showed little interest in us and we had nothing really to say to them. In their world we were interlopers, Dovid serving as the bridge that each crossed with caution to meet the other. Even then those hasidic enclaves had an underbelly, those who occupied the margins, looking for something more than what their communities could offer.

After a month or two I realized I had to make a decision. I was still living with my parents in Manhattan and spending more and more time in Brooklyn. I had been toying with religious observance but wasn't sure it was 
something I could maintain. It was hol ha-mo'ed (the intermediate days) of Sukkot, 1979. I woke up in a sweat with a high fever. Sitting up suddenly in bed it hit me. My time here was over. I needed to move to Brooklyn and immerse myself in the world of Torah.

\section{III}

\section{The Hasidic Underground and Yeshivah Life}

Life in Boro Park, Brooklyn, was a macabre experience of living in an alternative universe that was a subway ride away from a city that offered everything. I lived in a dilapidated house in a mixed hasidic and Hispanic neighborhood on the outskirts of Boro Park that Dovid had one lived in with his family before moving to the other side of Boro Park. They may have been evicted. One was never quite sure who was actually living in that house. Some of those I knew from Jerusalem had returned and then a variety of other stragglers, vagrants, hangers-on, or those simply travelling through inhabited that house at various times. If there was space on the floor we could accommodate one more. Both the hasidic and Hispanic neighbors were equally baffled as to who we were and what we were doing there. We were robbed many times, but the intruders eventually gave up because we had nothing worth stealing. One of the most memorable robberies happened while we were eating the third meal on Shabbat, singing hasidic niggunim together as the sky darkened. Little did we know that as we were singing, burglars had broken into a back room and stolen the backpack of someone who had just arrived from Jerusalem. The only thing of value, or that which we most lamented, were some tabs of LSD that were lost forever. I hope our Hispanic brothers and sisters had a nice trip.

I first began studying in a small study house in Crown Heights with a young Lubavitcher hasid named Baruch Wertzburger. I was contemplating moving to Crown Heights to attend Yeshivat Hadar Torah. Habad seemed liked a logical choice as it was much more structured than the more diffuse world of Boro Park, mirroring the more disciplined and conformist world of Habad and the more free-flowing world of Polish Hasidism. I even packed all my things in my small Mazda to move into the dorms in Crown Heights. I arrived late at night, parked my car on Eastern Parkway and spent the night in the yeshivah without unpacking. In the morning I walked around and decided it wasn't for me. So instead of unpacking my 
car I just pulled away and drove back to Boro Park. Habad Hasidism was compelling and uplifting, but there was something about the rebbe worship in Habad that turned me off. I attended numerous Farbrengens with the Lubavitcher rebbe and the intensity was enormous as he carried the room with his charisma, but day-to-day Crown Heights just seemed too cultish for me. Boro Park was more eclectic and more dysfunctional. I liked that. I continued coming to Crown Heights daily to Wertzburger's small classes in Habad Hasidism, beginning with Sefer ha-Tanya and then reading through some of the present rebbe's sihot. My Hebrew was getting much better and I began to get the map of the terrain of hasidic texts.

Eventually I needed a bigger yeshivah with more subjects of study. I stumbled upon a new yeshivah in Flatbush run by two roshei yeshivah, one a Lakewood-trained rosh yeshivah named R. Chaim Friedman, proficient in the Lithuanian style of learning, and the second a Satmar hasid named R. Yizhak Ashkenazi. Here I spent a little more than two years really honing my skills in Gemara and halakhah and continued studying Hasidism and Kabbalah with Dovid and his circle (of which I had become by that time an inside member). Learning the Lithuanian method of Talmud by Rabbi Friedman and the broader rather than deep method popular among hasidim was illuminating. Rabbi Ashkenazi was perhaps the first person I met who really knew the entire Talmud by heart. He was from the Aleksander hasidic dynasty-people referred to him as the Alekser Rebbe-and he set up a small hasidic shul in the basement of his house. The Alekser dynasty was founded by R. Shraga Feivel of Gritsa, who was student of R. Yizhak Worka, a contemporary of R. Menahem Mendel of Kotzk. R. Ashkenazi's family had drifted to Satmar in America, but he retained the stature of hasidic aristocracy and was viewed by others with reverence. Hasidim often wandering in the yeshivah to ask him questions or ask for money. He took a special liking to a few of us, especially me, perhaps because he knew Dovid and also saw I was heading in the hasidic direction, whereas most of my classmates were not. My clothing had become more and more hasidic in style, I wore a black hat and suit and white shirt all the time, and unlike many others in the yeshivah I was interested in Hasidism. I was appointed his driver, mostly because I was the one who had a car and had the proper dress for the occasion. We spent many evenings traveling around Brooklyn and sometimes to New Jersey and Monsey, New York, a religious town in Rockland Country, to raise money (what is called schnorring). R. Ashkenazi was a master. On one occasion we sat at an ornate dining room table of a rich Jew in Monsey. Conversation ensued but the topic of money was never mentioned. Then at one point, the man took out a checkbook, wrote 
a check, and slid it across the table. Without a break in the conversation R. Ashkenazi looked at the check and with no expression, slid it back to the gentlemen. The conversation continued. This went on two or three times until R. Ashkenazi put the check with the "right" amount into his pocket. Then we got up, shook hands, and left. That is how it is done.

One other person worth mentioning from that yeshivah was a rabbi named Yona Frankel, probably in his thirties, a modern Orthodox rabbi who lived in Long Beach, Long Island, but traveled every day to Boro Park to teach ba'alei teshuvah. He viewed it as something wondrous, and I felt this was his kind of pro bono for the cause of Torah. I studied Mishnah and Talmud with him for about a year, and his patience still remains with me. My most vivid memory of him was the time he asked me to drive him to deliver a hespid (eulogy) for an elderly woman who had died. We entered the chapel in the funeral home and I took a seat in the front and began reciting psalms, which is the custom. R. Frankel began delivering a long and impassioned eulogy for this woman. At some point I turned my head to the audience behind me. There was only one woman sitting there, the dead woman's caretaker. The rest of the chapel was empty. R. Frankel had been delivering this passionate eulogy for this one woman, or maybe not even for her. I had never encountered such a person growing up.

At this time, my relationship with Dovid was deepening and I become one of his close disciples. I use the term "disciple" carefully, as that is what we were. He served as a rebbe and spiritual guide and we treated him as such. We did constitute a "family" of sorts and, in retrospect, we probably would have met the bar of being considered a cult, but we were so integrated into the haredi community around us no one really noticed. Except one person.

In those days (the late 1970s) Aryeh Kaplan, who was already well known an Orthodox writer, lived on the outskirts of Boro Park. His books on Kabbalah had been published by Samuel Weiser, who owned a New Age press from Maine. This bothered some of the more conformist haredim in Boro Park, and thus I think Kaplan's decision to live on the margins of Boro Park was more than symbolic. An ultra-Orthodox Jew of Sephardic descent, who was a baal teshuvah himself, and once served as a rabbi in a Conservative synagogue (which in Boro Park is basically the same as a church), Kaplan decided to stay on the margins of that world. A deeply pious man, he would have an open house after Friday night dinner, and we sometimes walked there to listen to him. The neighborhood was not safe at night, and thus going to Kaplan's home itself required a modicum of emunah (faith). His dining room was adorned with a series of bizarre oil 
paintings. At some point, with no training as an artist, Kaplan decided to refrain from study for a year and devote himself to painting. After the year he stopped and never painted again. Those paintings were the product of his experiment.

He would gesture to someone to ask him a question about the weekly Torah portion and then he would just spin off of that for what seemed like hours (it probably wasn't). In any event, Kaplan emphatically did not like Dovid. It was a kind of fissure in the scene because there was a lot of overlap in those years between Dovid and Kaplan. Kaplan saw something in Dovid he didn't trust, but he didn't know what. We just never mentioned Dovid in Kaplan's presence. Many years later Kaplan's intuitions about Dovid turned out to be right. He was hiding something.

During this time, I began to integrate more into the haredi world even as we were always looked upon as different. But we were "walking the walk" so intensely, and seeing us at the mikveh at 5:30am on a freezing January morning before davenning made them respect us even as they probably would not allow us to marry their daughters. The quasi-monastic life we led was very conducive to me, and I began to feel like I was living like those Amish in Pennsylvania and the hasidim walking over the Brooklyn-Queens Expressway I had seen as a child. I felt like I had found some alterity. I was living "otherwise." I once got a phone call from a high school girlfriend. It happened to be Thanksgiving and she asked where I was eating Thanksgiving dinner. "Thanksgiving?" I responded. "Oh, I didn't know that." I smiled at that remark. I had found a way off the grid. She later told me she thought I was living in a crack house in south Brooklyn. Who in America doesn't know it's Thanksgiving? Welcome to hasidic Boro Park.

Hasidism opened itself to me as a textual tradition and a lived life simultaneously. I studied the texts and tried to live the life they professed, or expected. In the classic Augustinian sense, I took my return too far. I did not have the slight cynical edge many have who grow up in that world. Texts became an appendage: we carried them around (one always had a sefer with them in case they had a few minutes to open it), we read them on the subway, we spoke of them to friends in the street, at airports, on lines in supermarkets, at Shabbos tables. In those years I felt that studying Torah wasn't something we did, it was part of who we were. The line separating work from leisure did not exist. That itself was a kind of alterity. And yet we also lived it in subversive, countercultural ways. We allowed our past "hippie" lives a place at the table, as long as it played by the new rules. In that sense we had a secret from those around us. They had a right not to trust us. We were also interlopers, perhaps the worst kind, because we were offering 
a different rendering of their world, which seemed like a previous rendering of their world in terms of piety but a strange fruit culturally. Some of it came to the surface in culinary matters. We would bake whole wheat challah and rush it to our guests for Shabbos late Friday afternoon because we didn't eat processed flour. We introduced many hasidim to tofu, ginseng, vegetarianism, yoga, shiatsu, and health food. There were not many hasidic Jews in Boro Park who had tasted vegetarian cholent (a traditional hot Shabbat dish made of beans, potatoes, and meat) until we came around.

One of the great spaces of cultural syncretism in those years was a kosher macrobiotic restaurant on $6^{\text {th }}$ street between $1^{\text {st }}$ and $2^{\text {nd }}$ avenue in Manhattan called Caldron's Well. It also had a small health food store right next door. These were the late 1970s when punk was widespread. On a given night at the Caldron one could find a table of hasidim talking Torah, a table of punks with pink mohawks and safety pins through their cheeks talking music, hippies with small disheveled kids, a shidduch date of straight-looking Orthodox Jews who had chosen the wrong kosher restaurant, a table of Hari Krishna folks, and next to them, black jazz musicians on a break from a gig a few blocks away talking Coltrane. The founder of the restaurant was Moshe Schlass, an ex-biker hippie who had become a Lubavitcher hasid, who was a kind of master of ceremonies of the bizarre syncretism he loved. He eventually moved to the Old City of Jerusalem, where he lives today, and left the restaurant to his first wife, who ran it for another decade until she had a child late in life and sold it. The Caldron was the main hangout for many of us in those years. We would sit there drinking bancha tea for hours and talk, learn, just breathe in the vibe of the East Village. We felt part of the counterculture and we secretly liked that. It was there I first met Yossi Klein Halevi, who was a one-time member of Meir Kahane's Jewish Defense League and also part of the wider circle of Dovid's "boys," who had started a hip newspaper called The New Jewish Times. The front page of the inaugural edition in the late 1970s had a split screen photo of people at a raucous punk rock show and Friday night davenning at the Bobov hasidic synagogue in Boro park-a study in comparative contrast. We felt like we were making a mark.

When I think about my exposure to hasidic texts, I realize the very notion of critical study of these texts was so foreign, so utterly odd in those days, that I never thought much about it. I suppose we had the typical insider's critique that those "scholars" could not really understand these texts, because a full understanding would require living the life, being "on the path", as they say. Decades later, as I have spent a good part 
of my academic career doing just that, I can still sense the difference, and there is still some small voice in me that says, "If you hadn't been there in some fashion, something would be missed here." I don't know if I believe it, and I also think those there miss something precisely because of that "thereness." In any case, I can, and do, study these texts in a variety of often contradictory ways. My own academic approach does not eschew the traditional approach in principle. In fact, in my work on Hasidism I try to show that, in many cases, the texts lend themselves to the undoing of the traditional ways of reading them. This is not to suggest I have unearthed any esoteric meaning or have disclosed any essential nature of Hasidism. Rather, it is to suggest that the texts themselves contain multivalent layers and the lens one chooses to use as a reader can yield a variety of results that the texts themselves can sustain, even though in some cases those readings may stand in contradiction to one another. Here deconstruction has served me as a useful tool. My own allergy to normative readings of these texts comes in part because at a certain time in my life I was convinced that was the only way to read them. In that sense, my readings are products of my own internal battle with normativity and innovation.

Even during my years in Boro Park and haredi Jerusalem these texts we studied often seemed to some of us to rub against the grain of the world that used them as a template for life and practice. Perhaps that is because some of our teachers, like Dovid and Aryeh Kaplan, were teaching these texts in quite iconoclastic ways, not necessary by choice but by design. Neither had received the tradition from the inside alone, each came to it from the outside and then, gaining literacy in the tradition, began to teach themselves. Kaplan was much more adept textually and also more conservative, albeit not as pious, as Dovid. But in general, what was happening among the sub-cultural Boro Park ba'alei teshvah hasidim was a syncretistic exercise under the auspices of haredism. We were living the life, in many ways more fully than our hasidic neighbors, and we were spending the thousands of hours in study required to get our credentials. But we were a subculture. And although we would have denied it then, we were forming a new kind of neo-Hasidism.

This "movement" was being fed by Zalman Schachter, Shlomo Carlebach, the Diaspora Yeshiva Band, Habad, Bratslav, and the orientalist veneration of Eastern Europe. We knew about Buber, Heschel, Gershom Scholem, and even Joseph Soloveitchik-but they didn't interest us that much. We felt we were in the belly of the beast, and their writings were for outsiders: they were modern, they were not countercultural enough. We would rather just 
study the hasidic texts they were studying and skip the scholars as intermediaries. We had no idea that they had value as more than interpreters of Hasidism. Years later, I learned how wrong I was.

\section{IV}

\section{The Enigma of Over-Belief}

Life with Dovid was hard. Besides being obstinate and stubborn, he moved very slowly and deliberately, and he demanded others do so as well. Thus being with him meant slowing down your body clock. He also had a bizarre lack of fear. I recall walking or driving with him on Houston Street in Manhattan late at night after classes he gave at the Charles Street Synagogue in the West Village in the early 1980s. Dovid would often ask me to pull over and wait for him as he got out of the car to give a wino or a junkie on the street all the money he had. Or being stopped at a red light by a panhandler and Dovid rolling down the window and handing him a $\$ 20$ bill he got for his class as a donation. In those downtown neighborhoods, where we would go late at night to vegetable stands in Little Italy, Dovid was known by the winos and junkies as the "The Rabbi" because he would always give them money. Dovid was always on welfare, food stamps, etc.; he was real mendicant Jew, claiming his work was serving God. He wore black stockings and a long coat in the style of some hasidic Jews, and once when waiting on line at the Welfare Office, two black women on line ahead of him saw him, and one said to the other, "Girl, let that dude ahead of you in line. Look, the dude is so poor he ain't even got no pants!"

Davenning with Dovid could be uplifting and it could be maddening. He had a monastic cadence and took hours. Literally. And we all recited everything together in a kind of Tibetan or maybe closer to a Gregorian chant. Dovid had an amazing capacity for concentration and focus. Maybe more than I have ever witnessed. If you were able to tune into that wavelength it was exhilarating. If you were in a hurry, you felt like jumping out of the window.

We were once travelling together back from Israel to New York. We had an early morning flight and thus had to daven at Ben Gurion airport. Dovid refused to quicken his pace at all. It turned out the flight had almost completed boarding and he was still ending his davenning. I urged him to take off his tefillin and finish on the plane. He refused. By the time we arrived 
at the gate the attendant told us the gate was closed. I pleaded, and the woman finally agreed and let us go to the tarmac. A bus came to pick us up to bring us to the plane. When we arrived, security was standing in front of the steps to the plane and directed the driver not to open the door. On our way down I heard the woman upstairs complain to security that two hasidic Jews refused to finish their prayers and thus held up the flight. The plane door closed and we were driven back to the gate. I was furious. Dovid had no emotion whatsoever. He looked incredulous when I began to complain to him. "For something like this you are losing your temper?" Either the world conformed to his dictates or he gladly suffered the consequences.

We were redirected to a flight through Paris. When we arrived in Paris we found out there was an airport strike and no planes were departing. We had little money. We spent two days and two nights in the Paris airport drinking only water and eating only the peanuts that we had with us. Dovid refused to eat anything else because of kashrut. I was his disciple and I went along with his requests. But I was not happy about it. In those moments I felt like I had entered into the hasidic tales we read. Texts and life merged into one annoying mix. I learned that alterity has another side, that the extremism I romanticized often didn't take others into account, that piety too often trumped others who got in the way. It was an important lesson.

Learning with Dovid was both arduous and exhilarating. And here I think my initial understanding of Hasidism becomes apparent. The texts were not to be read, but one had to make Hasidism out of the Hasidism (and here I think Dovid was a master, even as he often read the texts wrong). That is, the texts were portals of ideas that one could read and explain and then do to them what they have just done to the tradition. I think Buber understood that better than Scholem. Scholem wanted to know what the texts said; Buber was interested in how they provide a template for how to think about serving God. Buber was not compelling for me at this early stage, because he was so intent on finding the essence he let external acts of piety through devotion dissipate. Buber wanted to create something really new. We were deeply enmeshed in the romanticism of the old. It was only years later that I began to see how deeply Buber understood this material. But secretly we too did not accept the old readings, and Dovid was offering something new-except his resistance to the tradition didn't go left but right. It was not that traditional norms demanded too much; it was that they did not demand enough. The kind of antinomianism of Buber became for Dovid a hypernomianism. Halakhah was just the beginning. He essentially became a Jewish monk (he was married and had a family but his devotional life was monastic). He answered Buber's move outward 
by a move inward to achieve a similar end, in my view. Buber would have understood Dovid more than Scholem would have.

Dovid didn't know Hebrew nearly as well as he thought he did. He knew it well enough; he could read Hebrew texts and explain them (often mispronouncing words but getting the meaning right). Many people who came from a traditional upbringing used to complain about Dovid's mispronunciations but were compelled enough by the content of what he said to return again and again. In any case, what the text was, or what the text said, took on more meaning once he began to expound on them. At that point the text became superfluous. In retrospect, some of it was second-rate New Ageism, but Dovid was really a poet by nature, and his use of language and imagery and his general education in the Humanities (he dropped out of college his senior year but had a Dylanesque ear for the poetic) enabled him to bring Nahman of Bratslav to life as if he was in conversation with Walt Whitman. Or Isaac Luria as if he were sitting with Rumi or Ibn Arabi. It was an interesting exercise. It's not that he actually quoted any of these non-Jewish sources very often. It is, rather, that his rendering of the texts we were reading were given a universal spiritualist appeal that spoke beyond the confines of their world. It was this unspoken synthesis that I think drew many of us to him; it enabled us to retain a part of the world we came from and not become swallowed up into a haredi world that was often not very pious. And not very interesting, and certainly did not have the aesthetic ear many of us thought, or hoped, Judaism possessed. Most of the hasidim we lived amongst were just ordinary people who happen to be born into a particular community. Some of them were indeed true gems of piety and devotion but they were the exceptions. And we knew that.

We envisioned Dovid as a leader of a kind of New Age hasidic syncretistic Judaism that could be both ultra-Orthodox and spiritually open. Rav Abraham Isaac ha-Kohen Kook coined the phrase "behaviorally constricted and thoughtfully expansive." We never studied Kook, because Kook was a Zionist and Dovid identified more with the anti-Zionist Neturei Karta or Satmar types. Had Dovid read Rav Kook, stripped of his Zionism, he would have liked him.

Dovid attended many ecumenical retreats and spoke as easily with a Buddhist monk as with a Trappist novice. His justification was always that it is "kiruv," finding wayward Jews to bring them back to Judaism. But in retrospect, I think he needed to get out of the haredi world he inhabited. He was far more critical of that world than he let us believe, but because they were largely clueless of what he was up to, and they provided a perfect place to hide, he remained part of that community. Looking back, I think 
my interest in comparative readings of hasidic texts with Christianity probably came from Dovid's spiritual ecumenicism that he got, in part, from Zalman Schachter years before. Dovid had worked for Zalman as a personal secretary when Zalman taught at the university in Winnipeg in the mid-1960s. After many of us left him in the mid-1980s Dovid began studying Christian theology with Ewert Cousins at Fordham University. Many years after Dovid died I inherited a few boxes of books on early Christianity and Gnosticism from the Fordham University library that were decades overdue. I still have some of them.

In those years a group of about eight of us lived in either Boro Park or Jerusalem. We usually had apartments in both places, and different combinations lived in either place. We were constantly going back and forth. One of the Boro Park houses was an old decrepit house on $42^{\text {nd }}$ street off 10th avenue, on the outskirts of Boro Park in a mostly Latino neighborhood. Besides those of us who were permanent residents, that is, our names were on the lease, the house was consistently inhabited by a variety of vagrants, misfits, and all manner of haredi and quasi-haredi riffraff. One guy who looked a like one of Fagan's boys from Oliver Twist always rode around in a wheelchair (that he did not need), wearing fingerless gloves, terrorizing hasidic locals. Another was so OCD that we found him late at night one Friday night in the middle of a side street in Boro Park. He would not move because he noticed a piece of lint of his coat and, since one is not permitted to carry on Shabbat (Boro Park has no eruv that would permit carrying), he thought he could not continue walking without "carrying" the piece of lint. And he could not brush it off because it was "muksa" (something that one cannot touch on Shabbat because it has no use). He was determined to stand there until Shabbat ended twenty hours later! It took us a full 30 minutes to convince him he was permitted to walk home with the lint on his coat. There are many other such bizarre incidents, but this suffices to give you a sense of the world I'd entered into.

\section{V}

\section{Aliyah and Kabbalah}

I finally moved to Jerusalem permanently in 1981. In part it was to break from Dovid and in part to settle into a more conventional haredi life in the Holy Land. I had no Zionist affiliations or aspirations whatsoever. I lived in a small apartment in the Old City of Jerusalem with a close friend without 
any electricity or hot water. We didn't pay the bill and they shut off the utilities, and we realized we didn't really need them. We went to sleep when it got dark and awoke around $4 \mathrm{am}$ to go to the mikveh and then daven with the sunrise (vatikin) at the kotel every morning. We lived downstairs from a kabbalist named R. Mordecai Sheinberger who had a kabbalistic yeshivah, Kol Yehuda, in the Old City. R. Sheinberger was from the Ashlag school of Kabbalah. Yehuda Ashlag (1885-1954) was a Polish kabbalist who moved to Jerusalem in 1922. He was somewhat of an iconoclast and is mostly well known for his commentary to the Zohar entitled Ha-Sulam (The Ladder). He also published a popular book called Talmud Eser Sefirot (On the Ten Sefirot) that became popular among Phillip Berg and The Kabbalah Centre people (Berg was a student of R. Yehuda Zvi Brandwein, a student of Ashlag). Dovid often used that book in some of his classes. We used to eat Shabbat dinner at the Sheinberger's every Shabbat, a beautiful but very poor family with many children. My roommate Baruch Gartner, now a well-known teacher of Hasidism in Jerusalem, and I asked R. Sheinberger to teach us. He said his schedule was very busy but if we woke him up at 2 am he would study with us until it was time for the morning davenning. So about four nights a week we would walk up one flight of stairs and lightly knock on his door at 2am and he would answer in a bathrobe and we would sit and study Zohar and Ashlag for a few hours. We did this through one entire winter.

I later studied Lurianic Kabbalah with R. Mordecai Attiah, a Syrian kabbalist from the Shalom Sharabi tradition who was very antagonistic toward Sheinberger and the Ashlag school. The original Sharabi (1720-1777) was a Yemenite kabbalist who immigrated to Palestine, where he founded the Beit El yeshivah in the Old City. The yeshivah building still stands, but the yeshivah moved to the Zikhron Moshe neighborhood at some point. $\mathrm{He}$ was one of the most celebrated kabbalists of the Lurianic school and composed the first comprehensive siddur with mystical intentions according to Lurianic teaching. His tradition lives on today in Nahar Shalom yeshivah in the Nahlaot neighborhood on Jerusalem that was led, when I was there in the 1980s, by R. Mordecai Sharabi (no relation to Shalom Sharabi). R Attiah's grandfather, also named Mordecai Attiah, who was a study-partner with Rav Kook, came from the Sharabi tradition, and so the younger R. Mordecai Attiah who I studied with was a part of that tradition. They did not look kindly upon the Ashlageans, thinking them a diluted and mistaken interpretation of Luria. When I began studying with R. Attiah my relationship with R. Sheinberger ended. They often sparred over publishing 
rights to various editions of kabbalistic texts and could barely hear the other's name mentioned.

I studied with R. Attiah for about three years. I entered the yeshivah wanting to study Lurianic Kabbalah. I asked him if I could enter his closed shiur every afternoon from $4 \mathrm{pm}$ to $6 \mathrm{pm}$. He assigned me texts to prepare for the shiur with his father R. Eliyahu Attiah, a sweet and learned man who knew the entire Tanakh by heart. Recite the first words of any verse and he could finish it without a mistake. We sat for a few hours and prepared the material. I recall we were studying a book called Da'at Tevunot of the Ben Ish Hai, R. Yosef Hayyim (1835-1909), a late nineteenth-century Baghdadi kabbalist. At 3pm I dutifully entered the room, which consisted of tables set up in a big square, each person taking his appointed seat. It was a mix of people from the yeshivah and various students of the grandfather for years, who worked in menial jobs. One was a bank clerk, and one was an old Jew with a long white beard named Yehezkel who was an exterminator. He arrived every afternoon with this grey exterminating uniform and equipment. When there was a particularly difficult question in the text R. Attiah always deferred to Yehezkel, who had studied for many years with R. Attiah's grandfather and was a master of this material, but always very humble. I felt it was a slice of old Jerusalem that few outsiders witnessed.

R. Attiah entered the room, shut the door, sat down, opened his book, looked at me and pointed toward the door. "Please leave," he said. Confused, and disappointed, I took my book and left. I told his father, who never attended the shi'ur, what had happened. He said, "Don't worry, we'll try again tomorrow." I repeated the same thing for over a week. I sat in my seat; he entered the room and summarily told me to leave. I was frustrated, but I really wanted to be part of the group. After about ten days or so, same story, he came in, sat down, opened the book, and looked at me. This time he smiled, stroked his beard, and then asked someone to read. I was in.

My time with R. Attiah was quite intense. I became very close with him and he rewarded my diligence with attention. He was not particularly enamored by Hasidism in general, and over time I began to alter my dress to be less hasidic. I retained my long payot but began to wear short coats and a more modern hat. I had become more immersed in Lurianic Kabbalah than Hasidism. Even after I left the yeshivah and then the Orthodox world, I still periodically go to visit him. On one visit I gave him a copy of my book on Lurianic Kabbalah, From Metaphysics to Midrash. He smiled and hugged me when I gave it to him, but I am quite certain he never read it. His spoken English was fine, but I cannot imagine he would have made the effort 
to read it. I hope it is still sitting somewhere on a shelf in his library. My understanding of hasidic texts was greatly enhanced by the years I studied with him. Since much of hasidic literature is based on the Lurianic system, knowing it as intimately as I did though his tutelage made me better prepared when hasidic literature became an academic profession.

During some of those years I would divide my time between Yeshivat ha-Mivtar, also known as "Brovinders," and R. Attiah's Yeshivat ha-Hayyim ve-ha-Shalom. I would study Gemara in the morning at Brovinders and Kabbalah in the afternoon with R. Attiah. R. Brovinder had a profound impact on me. In those years I was deeply invested in the haredi life. And yet there was something about me that still felt outside. R. Brovinder was born and raised in Brooklyn in the heart of postwar Modern Orthodoxy. He studied with Rav Soloveitchik at Yeshiva University and immigrated to Israel with many from his world in the years following the Six-Day War. A brilliant talmudist and gifted teacher, he also received his $\mathrm{PhD}$ in Semitic languages at the Hebrew University, studying with the philologist Moshe Goshen-Gottstein. Although modern in every sense, he was a deep believer in the yeshivah as an institution and the world of the yeshivah as a place where true innovative scholarship could take place. He knew Dovid Din from those of us who attended his yeshivah and, while skeptical, he enjoyed the quirkiness and also the diligence that many of us exhibited inside the walls of his institution. If you studied hard and asked good questions, you won his respect.

At a certain point, intrigued by those of us who were devotees of hasidic texts, R. Brovinder decided to try his hand at it. Friday mornings in yeshi$v a h$ are usually left for individual or elective study, as life turned to Shabbat by early afternoon. R. Brovinder established a Friday morning class in Nahman of Bratslav's Likkutei MoHaRan, one of the classic texts of early Hasidism. We thought it was a victory of sorts, getting this Litvak rosh yeshivah to study Likkutei MoHaRan with us. The shi'ur continued for a few years, and, looking back, it was pivotal for me as a student of Hasidism. It was the first time I had studied hasidic literature with someone who was outside the world of Hasidism. R. Brovinder read it as he would read any Jewish text, and one saw the joy he felt at realizing the interpretive genius of Nahman. While we felt we had some impact on him, it was really his approach that had a big impact on me. I learned what it was like to read a text outside its context, and not as a purely devotional act but as a critic as well. He later tried the same thing with Luria's Eiz Hayyim, but it was not successful. Eiz Hayyim requires a different set of skills and knowledge base than Hasidism. A yeshivah-trained rosh yeshivah with no real kabbalistic 
training could not easily crack the Lurianic nut. That itself was an interesting lesson for me as I moved forward.

For three years, from 1986-1989 we lived on Moshav Me'or Modi'im, a small communal town (moshav) near Lod founded in the late 1970s by disciples of Shlomo Carlebach. I think of it as there where I really began to understand how Carlebach's countercultural reading of hasidic texts served as the foundation for a certain kind of religiosity. And in some way I felt I had a window into seeing how hasidic communities are born years before they began to take shape. At that time, most of the members of the moshav were connected in some way Carlebach, who also had a house there and spent most of his summers using the moshav as his base of operations. There is much to write about life there and the people we lived with in close proximity, many of whom were and remain wonderful souls. But for my limited purpose here I learned to see how Ḥasidism in a "neo" register actually "worked" outside the normative framework of hasidic communities elsewhere.

It was there I experienced a different kind of hasidic focus on experience (deveikut), on camaraderie, on the shared sense of purpose that evolves from intense focus on one individual's view of the world, then the one I experienced in Boro Park or Me'ah She'arim. It was more close-knit, more countercultural, more confused in many ways, than traditional hasidic communities, and yet it contained an energy that was palpable and fructifying. Modi'im was also far less misogynist and paranoid than conventional hasidic communities. And I also experienced the way the focus on one charismatic leader creates all kinds of destructive elements and internal dissent. Yet at that time I remember thinking that in some way, that is the price, that the intensity and focus simply could not be generated and certainly not sustained without charisma. I learned many years later from Zalman Schachter-Shalomi that such charisma could transfer among various individuals within a community, that is, that the rebbe could be a function and not a person, what he called "rebbitude."

Modi'im differed from hasidic communities in other ways I found refreshing. Established hasidic courts read hasidic literature devotionally and try to emulate its values, but they are also very entrenched in habits and traditions developed long ago, and the communal structure is very invested in keeping them intact. This is part of what one could call hasidic conservatism. Neo-hasidic life at Modi'im in the mid- to late-1980s did not have the trappings or the weight of a tradition to maintain. Its members were creating their devotional life on the fly, as it were, many coming from the American counterculture with progressive values that were 
then recalibrated to conform to some manner of traditional hasidic life and contemporary Israeli society. This resulted in a variety of apparently contradictory values, for example, a broad and sincere openness to the world and a strident right-wing political stance on the question of Palestinians. A belief in the holiness of the land that often easily elided to the holiness of the state by some who in the U.S. protested the state, patriotism, and its warring policies. As one friend from Modi'im, who tragically died quite young, wrote on her Facebook profile regarding her political views, "Right on Israel, left on everything else." Modi'im was a study in contrasts, with Carlebach's vision of Hasidism its driving engine.

\section{VI}

\section{Ordination as an Exit Strategy}

It was at Brovinders that I received rabbinical ordination with a group led by R. Yaakov Warhaftig of Mechon Harry Fischel. After being examined orally and in writing by both Warhaftig and Brovinder, we were taken to an examination by R. Zalman Nechemia Goldberg who led a kollel in the Geulah neighborhood of Jerusalem where we also received a separate ordination. He was an intensely impressive man, then probably in his 60s, gentle, learned, and deeply pious. I did not know then that this ordination was, in a way, my diploma from Orthodoxy and would also enable me to make extra money when I became a graduate student in the U.S.

As time went on I began to feel more alienated from the haredi world. I felt questions I was asking were not being engaged, and the romantic world of Hasidism that Dovid introduced me to was really the creation of his own imagination. With him in Brooklyn and me in Jerusalem, the connection seemed more and more tenuous. And the more I knew, the more I saw that his textual prowess was indeed wanting. He knew that, and his stubbornness and stridency could not adjust. One could not move from being a student to a friend; his vision of himself and the world he wanted to create could not allow that. My relationship with him was ending and so was my infatuation with haredism. I walked into a barber shop on Me'ah Shearim Street in Jerusalem one Friday morning and asked the non-haredi Mizrahi barber to cut my long payot. He initially refused. I guess he didn't want to take the responsibility. I persisted. Finally, he obliged. I was looking for a way out. It seemed to me a physical change was the easiest place to begin. 
It was at this time that I began to think about life outside the haredi world. I decided to apply to be a candidate fellow at the Shalom Hartman Institute in Jerusalem. I also applied to the MA program in Jewish thought at the Hebrew University. I spent two years at Hartman where I was first exposed to scholarship on the texts I studied only in yeshivah. And it was there I came under the influence of David Hartman, a fascinating, if difficult, man whose erratic behavior one needed to suffer to understand his larger project of Judaism and modernity (he could treat you as a son one day and then act as if he didn't know you the next). I learned a great deal from him during those years, and in many ways in conjunction with Brovinder (they both studied with Soloveitchik in the 1960s) it turned me further away from the haredi world and toward academia. After two years at Hartman I moved to the rabbinic program at the Seminary of Jewish Studies, the academic arm of the Masorti (Conservative) Movement in Jerusalem. It was a very intense atmosphere, the learning was high quality, and I made close friends forged through the study and analysis of the textual tradition. It was there I studied with the renowned Bible scholar Moshe Greenberg, the talmudists Shamma Friedman and his brother Mordecai Akiva Friedman, and many other Hebrew University professors who taught there. At that point I had no intention of becoming a Conservative rabbi, I already had Orthodox ordination, but I was interested in critical Talmud study and that was the only way to get into Professor Friedman's Talmud class.

At the Hebrew University between 1984 and 1988 I was fortunate to have studied with some of the luminaries in the post-Scholem, Shlomo Pines, Natan Rotenstreich generation. I studied with David Flusser, Aviezer Ravitzsky, Marcel Dubois, Adi Zemah, Yermiyahu Yovel, and Paul MendelFlohr, among others. And in particular Eliezer Schweid. It was Schweid who would have the most lasting influence on me from the Hebrew University. I attended his seminar almost every semester I was there. One of the most lasting things about Schweid was the way he was able to embody the thinkers he was teaching or reading such that he channeled them in a way that seemed totally uncritical. Yet just as he drew you into the thought processes of a thinker, whether it was Maimonides, A. D. Gordon, Hermann Cohen, Nahman Krochmal, Hayyim Bialik, or Uri Zvi Greenberg, he began to offer his critique. It showed me that moving to the critical phase of analysis of any text before one enters deeply into it on its own terms weakens one's ability to be critical. I found this as a flaw in some scholarship I subsequently read, and this influenced my method of teaching as well. Before one criticizes a text one needs to understand it on its own terms. This at times requires a "suspension of disbelief" and at times setting aside one's own initial reasons 
for engaging the text, although, as Max Weber taught, one must also come back to those initial reasons later on. For those of us, and there were many, who moved from yeshivah-style learning, where critique was not part of the ethos, to academia, where criticism stands at the center of the scholarly enterprise, Schweid's method was both comforting and compelling. It has stayed with me throughout my career. Moreover, some of us who took the path from devotion to critique were never quite comfortable with the way those categories were viewed from both sides as contradictory. For me, the subjective and objective always lived in tension, and my academic scholarship and my sermons were different but also sometimes fed off one another in what I found to be interesting, and surprising, ways.

During those three years at the Hebrew University I never took a course in Kabbalah or Hasidism. I had studied those materials quite intensively in haredi circles and with R. Attiah, and when I entered the secular university I was more interested in philosophy and Jewish thought, something I had much less exposure to in yeshivah. When I decided to continue for a doctorate, Hasidism was not a subject that particularly interested me. I wanted to study the philosophy of history of Nahman Krochmal. When I arrived at Brandeis University in 1989 to study for my doctorate under the tutelage of the Maimonides scholar Marvin Fox, I took a required course in Jewish Bibliography taught by the Judaica librarian Charles Cutter (this was just on the cusp of computer technology and we did not utilize computers at all in this course). As a final paper we had to prepare an exhaustive bibliography of any subject and I chose early to mid-nineteenth-century Polish Hasidism for reasons that I have since forgotten. During my years in Boro Park and Israel I was often part of a circle that hung around Shlomo Carlebach, who often cited the Polish hasidic tradition, in particular R. Mordecai Joseph of Izbica, known as the Izbicher. So I complied a bibliography of the disciples of R. Simha Bunim of Pryzsucha (of whom Mordecai Joseph was one).

Through that exercise I once again became drawn to Hasidism, now as an academic subject. I felt I now had the critical tools to examine this material anew and the textual skills in both classical and hasidic Judaism to write an academic study. A book on the Izbicher had recently been published by a historian of Eastern European Jewry, Morris Faierstein, called All is in the Hands of Heaven, and since the Izbicher only published one book, Mei ha-Shiloah, I felt here was not enough room for another book on this enigmatic thinker. On the advice of a friend I began to explore the work of his grandson, R. Gershon Henokh of Radzin, a voluminous writer and editor of his grandfather's Mei ha-Shilo'ah. I had known about R. Gershon Henokh and even read some of his work but had never explored it in great 
detail. Upon examination I discovered a large trove of material, including a book entitled Ha-Hakdamah ve-ha-Petihah, a kind of historical prolegomenon to Hasidism, tracing its roots through the medieval philosophical and kabbalistic tradition. This brought together my interest in medieval Jewish philosophy, the philosophy of history, and Hasidism in a way that offered me a frame to think about the theological issues in the Izbica/Radzin tradition in a fresh way. I had found my subject which, in some way, is half the challenge.

With the years of study in haredi and traditional circles, which I had done without any pretense of a career, certainly not in academia, I entered the academic guild in the early 1990s. I felt somewhat of an outlier even as my yeshivah background, long beard, and large kippah gave me insider's privilege in those days. Many of my colleagues in graduate school had come from Ivy League universities, some from classical rabbinical seminaries. I came from a tiny experimental liberal arts college, Goddard College in Plainfield, Vermont, and years in the haredi world as a baal teshuvah. I had entered through the portal of an enigmatic hasidic teacher, Dovid Din, lived the life of a Bratslaver hasid, moved to the hippie/haredi Moshav Modi'im and the world of Shlomo Carlebach and Zalman Schachter, and had three small children and little money. I was far from the polished, button-down student that was more common in Jewish Studies graduate programs. But because of my time in yeshivah, and my "story," I was able to enter the guild through a side door.

Marvin Fox, an old-school Maimonides scholar and devout Orthodox Jew, for some unknown reason took a liking to me, appreciated the textual skills I came with, and supported my studies. One memory stands out. After I had submitted a chapter of my dissertation, he invited me to his home to talk about it. I nervously entered his home with a massive library. He told me to have a seat at the dining room table and he would join me in a moment. When I reached the table I saw the copy of the chapter I gave him, marked extensively with red ink and beside it a stack of about nine or ten hasidic books from the library. The books were the hasidic texts I was writing about. He obviously did not own them and had taken them out of the library to look up all the sources I cited. What struck me was both the seriousness with which he took the project and also how he viewed it as a learning opportunity to read hasidic works that he had never read throughout his long career. Fox was a proud man who took himself very seriously (we used to refer to him as F-x), but he could also be quite humble. He knew what he didn't know and was never too proud to learn something new. Michael Zank, now a professor at Boston University, and I were his 
last two students. He retired in the spring of 1994, the semester we both defended, and tragically died of non-smokers' lung cancer about a year later. I could not have asked for a more learned, honest, and generous man to launch my career.

A second faculty member with whom I had close contact at Brandeis was Michael Fishbane. Fishbane gave a graduate seminar every semester, an ongoing study of midrashic texts, that most of my cohort attended regularly. Trained as a Bible scholar, Fishbane was then making the transition to rabbinic literature and the study of myth, and we were, to some extent, his Guinea pigs. It was an exhilarating seminar, and although I can't recall quite how, I think I absorbed a lot of how he read texts-a rare combination of rigor and creativity-that I incorporated into my work on Hasidism.

The other person from that period with whom I had close contact was Professor Isadore Twersky of Harvard, who also served as a hasidic rebbe from the lineage of Talne. I was a regular at his small synagogue in Brighton, Massachusetts, and often attended his shiurim in the early 1990s. One afternoon the phone rang, and when I picked up a voice said, "Hello, this is Yitzhak Twersky, can I please speak to Shaul." I was so taken by the informalityYitzhak-I didn't know who it was at first. He called to ask if I would serve as a Teaching Fellow for a course he gave at Harvard on Aristotle, Aquinas, and Maimonides. Of course I agreed and spent the semester with three other graduate students at Harvard working for him. I never studied with Twersky formally but he readily read some of my work and offered many good suggestions. He was an exemplar of a scholar with integrity and honesty. I personally wished he would have been more outspoken and critical on some of the issues in the Orthodox community we inhabited but his reserved personality and extreme caution prevented him from doing so. When he died, the night before the funeral we all spent hours in his home with his body covered on the floor reciting Psalms, as is the custom. I remember walking up close to the body and expressing anger that he had left the world with so much left unsaid. As I saw it then, it was a missed opportunity.

\section{VII}

\section{Academia and Discovering Alterity Anew}

Scholars often claim they think "out of the box," but in reality academia is often a profession of boxes, and one's dissertation serves as a label. You are marked by that first work and it can take some time to erase that mark 
to pursue other scholarly interests. So I emerged in the academic world as a scholar of Hasidism. This always seemed strange to me because my interests were always much broader and because at the Hebrew University those labels do not quite fit. Many of those I studied with there, Eliezer Schweid for example, were quite eclectic in their interests. While in the U.S. they might be considered dilettantish, in Israel where the study of Judaism was part of the culture of the society, they were simply scholars of Judaica. Whether by inclination or training I saw myself similarly, or at least aspired toward that goal, yet I realized that I first had to make my mark from the box I created through my dissertation.

For the next decade or so I concentrated on carving a space for myself in the guild of academia. First at Rice University and then at the Jewish Theological Seminary I published academic articles in journals, revised my dissertation for publication, and played the role of a Jewish Studies academic. My interests were somewhat eclectic, including Jewish mysticism and Hasidism and medieval and modern Jewish thought. Rice was a great place to start and I made friends and learned much from my colleagues. My tenure at JTS from 1997-2004 was quite wonderful in many ways. I made relationships I keep to this day and I felt a part of a religious movement that, while not my own, was something I felt I could contribute to. It was here that I began to consider what it meant to be a Jewish public intellectual and hone the skills of functioning in the academy and outside it.

It was during those years, that I also felt I lost some of the alterity that drove me to Hasidism since I was a child, the sense of otherness and living otherwise that first attracted me to these texts and this world. The Conservative Movement stands very much in the mainstream of American Jewish life, and while the seminary offered me the opportunity to speak to a broader audience and to have a role in training Conservative rabbis for their lives in the pulpit, it also seemed a bit of an unnatural fit when some of my views became more eclectic and less conventional.

Once I became adept enough at academic parlance I began thinking about how the hasidic and kabbalistic texts I was reading could be used to make another kind of intervention, how can they be used against themselves as a template to describe a world other than their own. I was not drawn by any essentialist argument. By that time, I had been sufficiently influenced and convinced of post-structuralism and post-modernism such that I could not believe there was any essence to be discovered. But I still believed the texts were electric and were generative, even as I was often and increasingly critical of their assumptions and conclusions. 
The critical approach thus was not fully satisfying for me. I felt I needed a constructive component, and the question for me became how I could explore that, to express it, within the confines of academic discourse, or perhaps beside academic discourse. The academy is understandably very wary of such endeavors and thus the proper path of exploration was not simple. I did not want to abandon my perch in the academy. In some way this became one of the most challenging aspects of my intellectual career and spiritual life in those years. My station in history helped. I was living at a time when various critiques of modernity, broadly conceived, were growing roots in academia and particular in religious studies. The work of people such as J. Z. Smith and others in his wake opened up the possibility of thinking critically about religion without a sharp historical, or historicist, knife. The works of scholars such as Daniel Boyarin and Elliot Wolfson, the latter of whom was on my dissertation committee and remained an important colleague, mentor, and friend, enabled many of us to break free from the confines of how scholarship was previously defined. My desire was not to develop any confessional approach; rather it was to explore my material outside its own claims, enabling it to speak to contemporary issues and concerns.

In some way this was more natural, even expected, in the Israeli academic system where I began. Under the influence of Eliezer Schweid, Aviezer Ravitzky, David Hartman, among others, applied scholarship was if not a given then certainly accepted. Schweid in particular was interested in applied scholarship as it related to the culture of Zionism and collective existence in Israel more generally. Schweid viewed scholarship as generating culture as much as critiquing it.

But the early 1990s I had already decided to make my home in America and thus my interests turned more toward the American Jewish experience, initially in regard to religiosity and later culture more generally. By the time I arrived at JTS in 1997 I had all but left Orthodoxy. While still mostly observant, I became fully committed to egalitarianism and, more importantly, no longer identified with the Orthodox community. And yet my haredi past stayed with me internally, and my own religious life was lived largely refracted through the texts I read and the friends I read them with. For example, with a student and friend David Seidenberg, we began what David labeled the Hasidic Egalitarian Minyan, first at Anshei Hesed, a Conservative synagogue in Manhattan, and then in the basement of JTS. It lasted for three or four years, our attempt to draw together disparate but somehow also congenial approaches to Jewish life and practice.

Whereas Hasidism for me was once the counterculture I sought to embody, now it served a kind of ad hoc and under-theorized neo-Hasidism, 
which was intentionally misappropriating hasidic ideas and even behaviors. In the beginning this move to the margins of academia, where normative scholarly attention meets personal aspiration and inclination, was largely intuitive rather than reasoned, as I had no real sense of what to do with it or even whether to share it publicly in writing. I published a few small topical essays that experimented with these ideas but I had no real direction or even goal. I just knew, or hoped, that Hasidism and Kabbalah could be more than academically interesting and that I could somehow find a voice to express that in an academically responsible way.

In Hasidism on the Margin (2004) I tried to thread the needle of a serious academic study that would resonate with non-academics. One critical review claimed I was too inside the texts and too constructive in my interpretation. Perhaps in retrospect the critic was correct. I was not adept enough at the task. The problem was that I had no theoretical frame, no broader vision of what I wanted to do or what I wanted to say. In 2005 I was working on a book on Lurianic Kabbalah using a New Historicist lens to look at Lurianic metaphysics and the question of cultural production, that is, how the metaphysics creates history and does not record or respond to it. The book was later published as From Metaphysics to Midrash. During that time, I received a request from Jo Ellen Kaiser who was then an editor at Tikkun Magazine where I had published a few essays over the years. She asked if I would write an essay for Tikkun on contemporary Jewish Renewal. I received the invitation while I was living on Fire Island where I had a summer pulpit at the Fire Island Synagogue, an egalitarian synagogue in Ocean Beach, New York, where I have served as the rabbi since 1997. I had never really thought about Jewish Renewal as a subject of scholarly inquiry but something about it piqued my interest. Accepting the task, I had no idea it would provide for me the frame I lacked. And it would also serve for me as a new kind of alterity, in some way a looping back to a much earlier time in my life, an alternative to a purely scholarly life (not that anyone has one anyway) or at least an outlet for my scholarship that I found refreshing. With the salty air of the sea in my lungs, I began to think more seriously about Jewish Renewal.

\section{VIII}

\section{Jewish Renewal, Neo-Ḥasidism, and American Post-Judaism}

The essay I submitted on Jewish Renewal was far too long for a publication like Tikkun. Jo Ellen asked if I would be willing to divide and publish it 
serially, to which I agreed. It was published in three installments in 2005 and 2006. Only after delving into the thought of Renewal and its founder Zalman Schachter-Shalomi did I think about writing a book-length study of the topic. But I still felt the issue needed a broader frame. From this came American Post-Judaism. But more than that, through this project I became reacquainted with Schachter-Shalomi, whom I had met in the late 1970s at a wild Renewal Shabbat at the Freedom Farm outside Philadelphia. I am quite sure he did not recall meeting me, but we crossed paths numerous times after that when he used to visit his daughter and her family in Moshav Modi'im, where I had lived from 1986 to 1989.

During my research and writing of American Post-Judaism, which was not a book about Hasidism but was certainly a book that, in part, attempted to reimagine neo-Hasidism in a cultural and not only a religious register, I became quite close to Schachter-Shalomi and in some way again found the alterity I was seeking. This project also brought me back to where things all began for me. Dovid Din had been Schachter-Shalomi's secretary when he was the Hillel director at the University of Winnipeg in the mid-1960s, when Dovid showed up in a converted school bus with a group of hippies looking to buy land for their commune. The others went on their way and Dovid stayed behind to work for Schachter-Shalomi. Dovid's Jewish journey thus began with Schachter-Shalomi, and even as he went deep into the haredi world while Schachter-Shalomi took haredism and crafted it in his own image, there was something about Dovid, and the things I learned from him, that remained quite close to Schachter-Shalomi. And there was something about Dovid, a kind of wayward son, that Schachter-Shalomi never gave up on. Years after Dovid died tragically of complications from anorexia at the age of 46 in 1987, Schachter-Shalomi would ask me about his wife and children when we spoke on the phone. It seemed to me a combination of genuine care combined with a small dose of guilt.

As close as I felt to Schachter-Shalomi, I could not enter the Renewal world he created. I always remained on the margins, both because that is where I felt most comfortable and because many in that community did not quite trust my "academic" and "critical" assessment of their rebbe. Externally I had moved further away in terms of religious practice, and yet my haredi past was too embedded in my psyche to allow me to take the New Age as seriously as is required in order to enter that world fully.

In any case, after American Post-Judaism I returned to the study of Hasidism with new energy. I now felt free to look at these texts I loved with new eyes. Having moved to the Department of Religious Studies at Indiana University in 2004 I was now surrounded by other scholars of religion the 
way I had not been at JTS. And living in Indiana made me feel for the first time I was living in the kind of America that did not exist in New York City. American Post-Judaism was fully a product of that "American" experience, and my subsequent book, Hasidism Incarnate: Hasidism, Christianity, and the Making of Modern Judaism, was also a product of living in a multidimensional and multivalent academic community. I felt a kind of ownership of those texts in ways I had not before, a confidence that I had something to contribute to their continued relevance. Rather than viewing them solely within the orbit of Jewish life and practice, I argued that given the focus on the experience and proximity of God to the hasid, and given the notion of the hasidic zaddik as axis mundi (to borrow a locution form Art Green's popular and important essay) the parallels to Christianity were more than occasional, and worth tracing. The point was not to make direct connections, something that would be difficult if not impossible to do. Rather, I offered a phenomenological claim of similitude as a response to similar spiritual orientations and concerns coupled with the Zohar's polemic against Christianity by adopting Christian motifs that Hasidism absorbed without knowing of their polemical roots.

\section{IX}

\section{Coming Back to Ḥasidism Once Again}

The present volume collects a series of reflections on Hasidism that spans about twenty years. Most of the essays appeared elsewhere in scholarly journals or volumes; a few are new. They illustrate my struggle with hasidic texts, my closeness to them, and my distance from them. In retrospect perhaps they reflect more about me than about them, but all scholarship is, or should be, autobiographical. Academics in the humanities have the blessed opportunity to contemplate the world through a particular lens that both reflects and teaches them about the texts they read and the worlds they come from, and about themselves and why they find these texts so compelling, even, or precisely, when they disagree with them.

In any case, I hope to convey in these essays how the texts were a product of their time and remain alive, at least for me, not as exemplars of any lifestyle or practice, although they are certainly also that for some, but as exempla of the pursuits of consciousness and meaning, often through the creative misappropriation of traditional motifs to serve a different end. In this way, I suppose I return to Buber, albeit with a different focus. Unlike 
Buber I am not looking for a hasidic essence. That was for a different time. In these essays I am looking, perhaps, for an alterity that could open the texts to the world and shine light on the possible global implicactions at work in the recesses of a highly parochial tradition. In this sense I am taking Dovid Din's transnational monastic piety and Schachter-Shalomi's rendering of Renewal as the "fourth turning of Hasidism" to a new place. While Jewish collective existence remains important to me as a Jew, as a scholar of Hasidism and as one who hopes my work extends beyond those parochial parameters, I do not place Jewish "continuity" at the center of my intellectual and spiritual project. Although, as Hannah Arendt replied when asked about her being a Jew, "I can't quite think of being anything else."

Over the course of the years when these essays were written, I explored a variety of other subjects in my academic work and in topical writing. A book on Lurianic Kabbalah, on American Judaism, on the little-known Elijah Zvi Soloveitchik's Hebrew commentary to the New Testament, and many essays on modern Jewish thought, Mussar, Judaism and Christianity, and Zionism. A friend once noted laconically that I had "left Jewish mysticism behind." But that is not quite true. My interests have always been eclectic as far back as my adolescence, and my training at the Hebrew University mitigated against the American academic doctrine of focused expertise. Eliezer Schweid wrote on everything from the Hebrew Bible to globalization; my doctoral advisor at Brandeis, Marvin Fox, wrote on everything from rabbinic literature to Kant, even though he was primarily a Maimonides scholar.

But wherever my restless mind and heart may have led me, I always seem to come back to Hasidism. There is something in its mix of metaphysical speculation and its messy depiction of the human condition that never grows old for me. To me, hasidic literature feels like an old friend who knows you well and who has been with you on a long journey, and in and with whom you always find something new. Like an old friend, it is in relation, what Buber liked to call the "in-between" where real insight occurs. These essays are an example of that "in-between." Not always loving, not always joyous, not always satisfying. I am not sure the hasidic texts I examine here are, as one scholar described Hasidism, "words of fire." But they are certainly words that breathe life into this Jew trying to find his way in the world. Thus far I have come. Ashreinu mah tov helkeynu ("oh to be happy with one's lot"). 
